\title{
THE WORKS OF HERCULES AND COVID-19 LESSONS FOR MEDICAL EDUCATION
}

\section{OS TRABALHOS DE HÉRCULES E AS LIÇÕES DA COVID-19 PARA A EDUCAÇÃO MÉDICA}

\author{
Hercílio Martelli Júnior ${ }^{I, I I I}$ \\ Renato Assis Machado II (iD \\ Mário Sérgio Oliveira Swerts ${ }^{I I I}(\mathbb{D}$ \\ Daniella Reis Barbosa Martelli ${ }^{I}$ (D) \\ Antônio Prates Caldeira ${ }^{I}(1)$
}

Dear Editor,

In the last twenty days (between March 19 and April 7, 2020), when we searched for the word "Coronavirus" in PubMed (https://www.ncbi.nlm.nih.gov/pubmed/), 1,145 scientific papers were found, a daily average of 57.25 papers/day. Scientific papers discussed several aspects of the COVID-19 pandemic, including people's and health care providers' mental health, public policies, drug development and vaccines. However, few studies have been published on medical education and activities during this quarantine period. ${ }^{1,2,3}$

By March $1^{\text {st }}, 2020,58$ countries besides China had confirmed COVID-19 cases. Now, on April $10^{\text {th }}$, there have been a total of 1,521,252 confirmed cases in more than 200 countries and 92,798 deaths (https://www.who. $\mathrm{int/docs/default-source/coronaviruse/situation-reports/20200410-sitrep-81-covid-19.pdf?sfvrsn=ca96eb84 \_ 2).}$ On March $11^{\text {th }}, 2020$, Tedros Adhanom Ghebreyesus, the World Health Organization (WHO) Director-General reported at the media briefing on COVID-19, among other things: "WHO has been assessing this outbreak around the clock and we are deeply concerned both by the alarming levels of spread and severity, and by the alarming levels of inaction; we have therefore made the assessment that COVID-19 can be characterized as a pandemic. Pandemic is not a word to be used lightly or carelessly. It is a word that, if misused, can cause unreasonable fear, or unjustified acceptance that the fight is over, leading to unnecessary suffering and death." (https://www.who.int/dg/speeches/detail/who-director-general-s-opening-remarks-at-the-media-briefing-oncovid-19---11-march-2020). With these expressive and alarming numbers, we have asked, how are the activities being developed in medical schools in different countries?

It has been observed by medical schools, through their pedagogical and information technology sectors, the generation of manuals and guides for teachers and students to provide access in near real-time. Electronic platforms, video conferencing networks and social media are being used for theoretical purposes. Educational electronic platforms are the official means that educational institutions have been using as an alternative to nonclassroom activities. Social media are widely used as alternatives for teaching. Instagram, Facebook, WhatsApp, Telegram and YouTube have all been used. ${ }^{4}$

In the Greek mythology, one of the best-known legends refers to the twelve works of Hercules. All of them comprised tasks with significant difficulties in the search for survival. Making an analogy with the medical education during these times of pandemic, one can outline some reflections involving teachers, students and the institutions themselves.

1. Many teachers do not have the mastery of information technologies as the younger ones do and make use of.

2. In several countries, virtual platform systems have shown problems and limitations due to the increasing level of use.

3. An important number of teachers are currently in the practical field, working in different sectors and services related to the pandemic and keeping distance learning activities.

4. It is noteworthy that in their homes, both teachers and students have had an intense change in logistics and routine services. For example, they do not rely on domestic helpers. 
5. Many of these teachers have children, who are currently without face-to-face activities at schools. And many of these schools are also adopting virtual classes and activities. However, during this period, all the responsibilities fall to the parents.

6. There is a growing emotional factor that the pandemic is imposing on this group of students and teachers.

7. The need for these teachers and students to receive pedagogical and emotional support, when necessary, should be carefully considered and planned.

8. There are uncertainties and limitations regarding the legal understanding of many countries about teaching activities during this pandemic period.

9. An important number of teachers at this time are focused on basic and clinical research involving coronavirus and living with everyday uncertainties and pressures.

10. In several countries, government agencies have discontinued financial investments aimed at research projects while demanding immediate results. ${ }^{5}$

11. The government's responsibilities and the law and limits imposed by the quarantine also affect potential learning during this period. ${ }^{6,7}$

12. The uncertainties imposed by the current moment and the limitations of future projections accentuate concerns about medical education, which is usually expensive.

After these twelve points have been laid out for reflection, one can make two important remarks: first: "I hope this story has helped you step back from the craziness and busyness of addressing the practicalities of medical education during a pandemic, to reflect on your own emotional response to COVID-19", ${ }^{2}$ and second: the history of epidemics offers considerable advice, but only if people know the history and respond with wisdom. ${ }^{8}$

And finally, one should remember: Hercules sought immortality. We are seeking improvements in the medical education model that the pandemic presented to us, and solidarity and successful collaborations and experiences are essential to overcome these challenges.

\section{ACKNOWLEDGEMENT}

The Minas Gerais State Research Foundation (FAPEMIG, Minas Gerais, Brazil), the National Council for Scientific and Technological Development (CNPq, Brazil), and the Coordination of Training of Higher Education Graduate Foundation (CAPES, Brasilia, Brazil).

\section{REFERENCES}

1. Bauchner H, Sharfstein J. A Bold Response to the COVID-19 Pandemic. JAMA [Internet]. AMA; 2020 Apr 8; Available from: http://dx.doi.org/10.1001/jama.2020.6166

2. Cleland J. Resilience or resistance: A personal response to COVID-19. Med Educ [Internet]. Wiley; 2020 May 4; Available from: http:// dx.doi.org/10.1111/medu. 14170

3. Eva KW, Anderson MB. Medical Education Adaptations: Really Good Stuff for educational transition during a pandemic. Med Educ [Internet]. Wiley; 2020 Apr 16;54(6):494-494. Available from: http:// dx.doi.org/10.1111/medu.14172

4. Machado RA, de Souza NL, Oliveira RM, Martelli Júnior $H$, Bonan PRF. Social media and telemedicine for oral diagnosis and counselling in the COVID-19 era. Oral Oncol [Internet]. Elsevier BV; 2020 Jun;105:104685. Available from: http://dx.doi.org/10.1016/j. oraloncology.2020.104685

5. Thorp HH. This is real. Science [Internet]. Science; $2020 \mathrm{Mar}$ 27;368(6486):7-7. Available from: http://dx.doi.org/10.1126/science. abb9223

6. The Lancet. COVID-19: learning from experience. The Lancet [Internet]. Elsevier BV; 2020 Mar;395(10229):1011. Available from: http://dx.doi.org/10.1016/s0140-6736(20)30686-3

7. Parmet WE, Sinha MS. Covid-19 - The Law and Limits of Quarantine. N Engl J Med [Internet]. Massachusetts Medical Society; 2020 Apr 9;382(15):e28. Available from: http://dx.doi.org/10.1056/ nejmp2004211

8. Jones DS. History in a Crisis - Lessons for Covid-19. N Engl J Med [Internet]. Massachusetts Medical Society; 2020 Apr 30;382(18):16813. Available from: http://dx.doi.org/10.1056/nejmp2004361

\section{AUTHORS' CONTRIBUTIONS}

H. Martelli-Junior contributed to conception, design, data acquisition and interpretation, drafted and critically revised the manuscript. R.A. Machado, D.R.B. Martelli, M.S.O. Swerts, and A.P. Caldeira contributed to conception, design, data acquisition and interpretation and critically revised the manuscript. All authors gave their final approval and agree to be accountable for all aspects of the work.

\section{CONFLICTS OF INTEREST}

None to be declared.

\section{ADDRESS FOR CORRESPONDENCE}

Renato Assis Machado.

E-mail: renatoassismachado@yahoo.com.br 